\title{
Bicuspid aortic valve aortopathy is not cancer
}

\author{
Thoralf M. Sundt, MD
}

\author{
From the Division of Cardiac Surgery, Department of Surgery, Massachusetts General Hospital; and the \\ Department of Surgery, Harvard Medical School, Boston, Mass. \\ Disclosures: Author has nothing to disclose with regard to commercial support. \\ Received for publication April 1, 2017; accepted for publication April 1, 2017; available ahead of print May 9 , \\ 2017. \\ Address for reprints: Thoralf M. Sundt, MD, Division of Cardiac Surgery, Department of Surgery, Massachusetts \\ General Hospital, Edward D. Churchill Professor of Surgery, Harvard Medical School, 55 Fruit St, Boston, MA \\ 02114 (E-mail: tsundt@mgh.harvard.edu). \\ J Thorac Cardiovasc Surg 2017;154:419-20 \\ $0022-5223 / \$ 36.00$ \\ Copyright (c) 2017 by The American Association for Thoracic Surgery \\ http://dx.doi.org/10.1016/j.jtcvs.2017.04.001
}

In this issue of the Journal, Vallabhajosyula and colleagues ${ }^{1}$ ask the question, "Is it necessary to replace the sinuses of Valsalva in the setting of bicuspid aortic valve aortopathy?" They leverage their enormous institutional experience to find an answer. The results suggest that this answer is "no." At least not in all cases.

This is an important question given the number of individuals with bicuspid aortic valve ( $1 \%-2 \%$ of the population), the frequency of aortic dilatation or aneurysm $(30 \%-50 \%)$, and the increasing frequency of aortic intervention in this population. ${ }^{2}$ The findings of this study argue for us to take a step back and ask how much really need be done.

To be sure, it is hard to ask a surgeon to do less rather than more; however, the balance of judgment has to be between the operative risk of the more aggressive approach and the natural history of the disease. In other words, what does it "cost" to be aggressive, and what do we gain? One is well advised to recall John Hunter's admonition, "No surgeon should approach the victim of his operation without a sacred dread and reluctance." At what point may we be doing more harm than good?

The answer to this question would require us to know with some precision (1) the incremental operative risk of root replacement relative to root preservation and (2) the risk of late sinus segment degeneration. The evidence here suggests that the answer to the latter-at least for patients with a sinotubular junction/annular diameter ratio smaller than 1.5-is "not much." This is consistent with the findings of others studies as well.

So, what about the incremental risk of the more aggressive approach? Although it is hard to find data comparing the operative risk of root replacement with a separate valve and graft (what these authors ${ }^{1}$ call "AVRSCAAR") in truly matched populations, some data do suggest similar operative outcomes. ${ }^{4,5}$ At the same time, others have argued that, at least in "experienced hands," adding an ascending graft to aortic valve replacement adds negligible risk. ${ }^{6}$ Data from the Society of Thoracic Surgeons database, however, indicate that the operative risk of aortic root replacement is

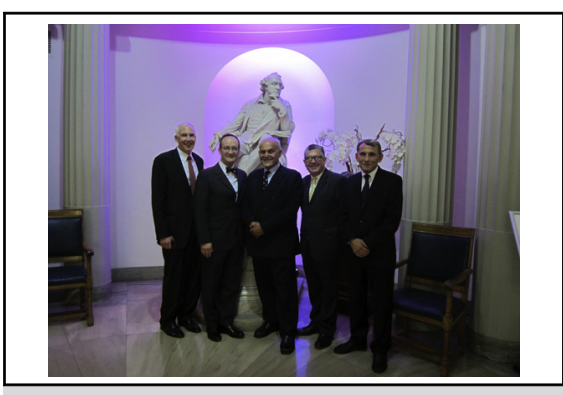

T.M.S. with mentor Sir Magdi Yacoub and friends Rocky Daly, Kenton Zehr, Samad Tadjkarimi.

\section{Central Message}

Estimates of surgical risk derived from retrospective series can be misleading and pose a genuine epistemological problem for those trying to balance risks and benefits of prophylactic procedures.

See Article page 421.

significantly higher than that for aortic valve replacement alone, $^{7}$ even at experienced centers. ${ }^{8}$ But if $\mathrm{A}=\mathrm{B}$, and $\mathrm{B}=\mathrm{C}$, how can it be that $\mathrm{A}>\mathrm{C}$ ? Clearly, the answer is subtle patient selection, as is the case in any good surgical series. Good judgment is the silent partner to "experienced hands" and good judgment means patient selection. This paradox highlights the dangers of estimating operative risk from retrospective surgical series.

Bicuspid aortic valve aortopathy, it would appear, is not cancer after all. Regardless of theoretic arguments that are based on embryology and the migration of neural crest cells, it does not appear to require resection to "clean margins," even if we believe that the operative risk "in our hands" is low.

My question to the authors ${ }^{1}$ now is this: Is it really necessary to replace the arch?

\section{References}

1. Milewski RK, Habertheuer A, Bavaria JE, Siki M, Szeto WY, Krause E, Korutla V, Desai ND, Vallabhajosyula P. Fate of remnant sinuses of Valsalva in patients with bicuspid and trileaflet valves undergoing aortic valve, ascending aorta, and aortic arch replacement. J Thorac Cardiovasc Surg. 2017;154:421-32.

2. Opotowsky AR, Perlstein T, Landzberg MJ, Colan SD, O' Gara PT, Body SC, et al A shifting approach to management of the thoracic aorta in bicuspid aortic valve. J Thorac Cardiovasc Surg. 2013;146:339-46.

3. Park CB, Greason KL, Suri RM, Michelena HI, Schaff HV, Sundt TM III. Fate of nonreplaced sinuses of Valsalva in bicuspid aortic valve disease. $J$ Thorac Cardiovasc Surg. 2011;142:278-84.

4. Sundt TM III, Mora BN, Moon MR, Bailey MS, Pasque MK, Gay WA Jr. Options for repair of a bicuspid aortic valve and ascending aortic aneurysm. Ann Thorac Surg. 2000;69:1333-7. 
5. Nazer RI, Elhenawy AM, Fazel SS, Garrido-Olivares LE, Armstrong S, David TE The influence of operative techniques on the outcomes of bicuspid aortic valve disease and aortic dilatation. Ann Thorac Surg. 2010;89:1918-24.

6. Rinewalt D, McCarthy PM, Malaisrie SC, Fedak PW, Andrei AC, Puthumana JJ, et al. Effect of aortic aneurysm replacement on outcomes after bicuspid aortic valve surgery: validation of contemporary guidelines. J Thorac Cardiovasc Surg. 2014;148:2060-9.
7. Rankin JS, Hammill BG, Ferguson TB Jr, Glower DD, O’Brien SM, DeLong ER, et al. Determinants of operative mortality in valvular heart surgery. $J$ Thorac Cardiovasc Surg. 2006;131:547-57.

8. Hughes GC, Zhao Y, Rankin JS, Scarborough JE, O'Brien S, Bavaria JE, et al. Effects of institutional volumes on operative outcomes for aortic root replacement in North America. J Thorac Cardiovasc Surg. 2013;145: 166-70.

Access to The Journal of Thoracic and Cardiovascular Surgery Online is reserved for print subscribers!

Full-text access to The Journal of Thoracic and Cardiovascular Surgery Online is available for all print subscribers. To activate your individual online subscription, please visit The Journal of Thoracic and Cardiovascular Surgery Online, point your browser to http://www.mosby.com/jtcvs, follow the prompts to activate your online access, and follow the instructions. To activate your account, you will need your subscriber account number, which you can find on your mailing label (note: the number of digits in your subscriber account number varies from 6 to 10 ). See the example below in which the subscriber account number has been circled:

\section{Sample mailing label}

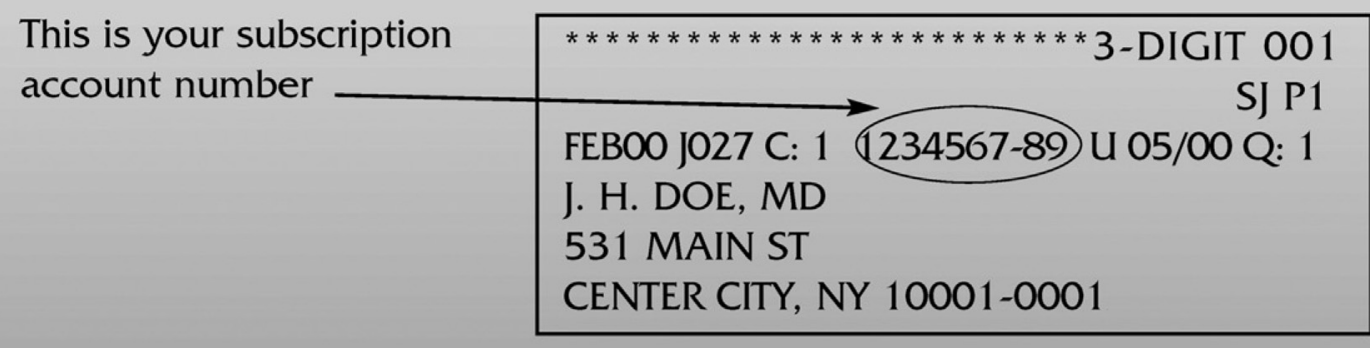

Personal subscriptions to The Journal of Thoracic and Cardiovascular Surgery Online are for individual use only and may not be transferred. Use of The Journal of Thoracic and Cardiovascular Surgery Online is subject to agreement to the terms and conditions as indicated online. 